\title{
Diversity of cultivable bacteria involved in the formation of macroscopic microbial colonies (cave silver) on the walls of a cave in Slovenia
}

\author{
Blagajana Herzog Velikonja ${ }^{1}$, Rok Tkavc ${ }^{1,2}$, and Lejla Pašić ${ }^{1 *}$ \\ ${ }^{1}$ Chair of Molecular Genetics and Biology of Microorganisms, Department of Biology, Biotechnical Faculty, University of Ljubljana, Večna pot 111, \\ SI-1111 Ljubljana, Slovenia \\ ${ }^{2}$ Henry M. Jackson Foundation for the Advancement of Military Medicine, 4301 Jones Bridge Road, Bethesda, MD 20814-4799, USA
}

\begin{abstract}
Karstic caves often support white, yellow, grey or pink microbial colonies that are termed 'cave silver' by speleologists. Using various sample pre-treatments and culture media, a wide variety of bacteria associated with these colonies were recovered from a cave in Slovenia, Pajsarjeva jama. Decreasing the inoculum size resulted in significant increases in viable counts, while pre-treatments had the opposite effect with the exception of microwave irradiation. While all growth media yielded viable counts, the maximal counts were observed on a low-nutrient TWA medium.

Based on the 16S rRNA gene sequence of OTU representatives, the majority of the 80 isolates examined belonged to Streptomyces (25\%), Micrococcus (16\%) and Rhodococcus $(10 \%)$ Other abundant groups were Pseudomonas (9\%), Agrobacterium (8\%), Lysobacter (6\%) and Paenibacillus (5\%), while members of genera Microbacterium, Agrococcus, Arthrobacter, Bacillus, Kocuria, Oerskovia, Sphingomonas, Aerococcus, and Bosea represented a minor portion of cultivable diversity encountered. Members of Streptomyces and Agrobacterium were common to all samples. Although these microorganisms readily form colonies under laboratory conditions, they were unrelated to abundant environmental phylotypes recovered from same samples in a previous study. However, the comparative 16S rRNA analysis showed that microorganisms highly related to the ones obtained in this study were cultivated from other subterranean environments indicating that they might represent true microbial cave dwellers.
\end{abstract}

Keywords: cave; bacteria, microbial colonisations; cultivation; $16 \mathrm{~S}$ rRNA

Received 7 May, 2013; Revised 13 October 2013; Accepted 4 December 2013

Citation: Herzog Velikonja B., Tkavc R. and Pašić L., 2014. Diversity of cultivable bacteria involved in the formation of microbial colonies (cave silver) on the walls of a cave in Slovenia. International Journal of Speleology, 43 (1), 45-56. Tampa, FL (USA) ISSN 0392-6672 http://dx.doi.org/10.5038/1827-806X.43.1.5

\section{INTRODUCTION}

Caves were long considered to support only rare microbial specialists (Palmer et al., 1991; Barton \& Jurado, 2007). Most cavern microbiota was considered to be imported from the surface through air currents, water, sediments, animal or human vectors and thus not specialized for subterranean life (Palmer et al., 1991; Keswick et al., 1982; Cunningham et al., 1993; Northup et al., 1994, Rusterholtz \& Mallory, 1994). Beginning in the 1990's, the use of molecular techniques quickly established that caves are in fact endowed with diverse microbial communities (Barton \& Jurado, 2007). The microbes present within caves were found to acquire energy using a plethora of approaches. These ranged from breaking down complex surface-derived aromatic compounds to oxidizing reduced inorganic compounds within the cave rocks. More importantly, the microbial diversity encountered was surprisingly high compared to what was expected given the amount and complexity of nutrients available in subterranean environments. This apparent violation of competitive exclusion or the 'one species-one niche' requirement (Hardin, 1960) led scientists to believe that within caves the selfish competition for resources is replaced by more cooperative and mutualistic microbial associations (Barton \& Jurado, 2007).

One eye-catching example of cave microbes are those found in Karstic and in lava caves which morphologically resemble white, yellow, grey, or pink bacterial colonies. Where present, these colonies can be observed throughout the cave as distinct one-millimetre 
size spots or can form thin (up to $1 \mathrm{~mm}$ thick) biofilmlike coatings that can be several square meters in size. This type of microbial growth, sometimes referred to as 'cave silver', is often covered with water droplets and reflects light in characteristic fashion, hence its name.

Over the years a number of studies have focused on cave silver samples from caves in Spain, Portugal, Hawai'i, New Mexico, Czech Republic and Slovenia. DGGE fingerprinting and phylogenetic analysis of $16 \mathrm{~S}$ rRNA genes obtained from cave silver samples from Spanish caves showed that regardless of its colour, they are dominated by members of Proteobacteria and Actinobacteria. The cave silver colonies supported various other phylotypes affiliated with Actinobacteria, Bacteroidetes, Gemmatimonadetes, Firmicutes, Planctomycetes and Nitrospira (Schabereiter-Gurtner et al., 2004; Portillo et al., 2008, 2009). An independent $16 \mathrm{~S}$ rRNA study that focused on cave silver in Slovenia showed similar results. This study also reported the presence of Verrucomicrobia and Chloroflexi (Pašić et al., 2010), which had been previously undetected. Members of the above listed phyla dominated a morphologically similar growth in lava caves in New Mexico, Portugal and Hawai'i (Northup et al., 2008; Garcia et al., 2009; Moya et al., 2009; Northup et al., 2011). Recently, a comparative analysis of environmental 16S rRNA from samples recovered from yellow cave silver growing on the walls of caves in Spain, Slovenia, Czech Republic, Portugal and Hawai'i found that all these caves support similar colonisations and have a common core composed of actinobacterial Pseudonocardinae and Gammaproteobacteria (Porca et al., 2012).

Investigations of cave silver have included cultivation efforts, however initially there were no published reports assessing the cultivable portion of microbial diversity. They are instances where cave isolates have been reported (Mulec, 2008) and three novel species were described from white colony samples taken from an Altamira cave (Jurado et al., 2006; 2008; 2009). These corresponded to the taxa that constitute a minor portion of the community, as is frequently the case with these studies. Regardless, cultivation is an important part of the description of a microbial community as the readily cultivated rare taxa represent a reservoir of biological diversity that is seldom retrieved in molecular studies. Our present study describes the bacterial diversity of the cultivable fraction of yellow, grey, pink and white cave silver colonies that develop in Pajsarjeva jama, Slovenia which were recovered using approaches successfully utilized previously in similar subterranean systems.

\section{MATERIALS AND METHODS}

\section{Sample collection and processing}

Microbial cave wall colonies were sampled in May 2011 in a $55 \mathrm{~m}$ long cave, Pajsarjeva jama, located $20 \mathrm{~km}$ south-west of Ljubljana, Slovenia $\left(45^{\circ} 49^{\prime} 51^{\prime \prime} \mathrm{N}\right.$, $\left.14^{\circ} 16^{\prime} 15^{\prime \prime} \mathrm{E}\right)$. At the time of sampling, the air temperature was $12.0{ }^{\circ} \mathrm{C}$, and the relative humidity was $100 \%$. Previous cultivation-independent studies found no differences in structure and membership of microbes in cave silver samples of same colour (Porca et al., 2012). This allowed us to collect four samples that corresponded to yellow, grey, pink and white cave silver morphotypes. We sampled areas in which the respective colour morphotype covered an area of several square centimetres. The samples were carefully scraped off with a sterile scalpel into sterile vials without touching the supporting rocks, were stored on ice and processed within $2 \mathrm{~h}$ after collection.

An aliquot $(0.05 \mathrm{~g})$ of each of the four samples was resuspended in $5 \mathrm{ml}$ of $0.9 \% \mathrm{NaCl}$ and divided into 1 $\mathrm{ml}$ subsamples. These were each treated as described in Niyomvong et al. (2012) in order to elicit the growth of non-Streptomyces Actinobacteria. The suspensions were either exposed to wet heat (water bath at $50{ }^{\circ} \mathrm{C}$ for 5 minutes); dry heat $\left(120{ }^{\circ} \mathrm{C}\right.$ in a hot air oven for $1 \mathrm{~h}$ ); dry heat and phenol ( $1 \mathrm{ml}$ of suspension was added to $9 \mathrm{ml}$ of $1.5 \%$ phenol solution and was incubated at 120 ${ }^{\circ} \mathrm{C}$ in a hot air oven for $1 \mathrm{~h}$ followed by 30 minutes at room temperature); microwave irradiation (frequency of $2460 \mathrm{MHz}$ and a power setting at $100 \mathrm{~W}$ for $45 \mathrm{sec}$ ); or remained untreated.

\section{Media and cultivation conditions}

Prior to plating, the treated suspensions were diluted to $10^{-3}$ in $0.9 \% \mathrm{NaCl}$. One hundred microliters of each dilution was spread onto seven different media. We chose media that contained substrates that are likely present in the natural environment and/or were previously shown to initiate the growth in a wide variety of cave organisms (Jurado et al., 2006; 2008; 2009; Niyomvong et al., 2012). Media included glycerol-asparagine agar (GAA) (ISP medium $\mathrm{N}^{\circ} 5$ ), peptone-yeast extract-brain heart infusion agar (PY-BHI) (Yokota et al., 1993), 1000-fold-diluted tryptic soy agar (TSA) (Difco, USA), starch-casein agar (SCA) (Wellington \& Cross, 1983), malt-yeast extract agar (MYA) (Oxoid, USA), soil extract agar (SEA, 1.5\% agar in 10\% (w/v) filtrate of soil in tap water) and tap water agar (TWA, 1.5\% agar in sterilized tap water). All media was supplemented with the fungal inhibitor nystatin (Sigma, USA, $100 \mathrm{mg} / \mathrm{ml}$ ).

Plates were incubated at $30{ }^{\circ} \mathrm{C}$ as suggested by Laiz et al. (2003), who found that low temperatures $\left(13^{\circ} \mathrm{C}\right)$ reduce the viable counts and the diversity of isolates related to Actinobacteria (but yield somewhat higher diversity of other Bacteria). During the five week incubation, the plates were opened periodically for colony counts. Morphologically different colonies were purified by streak-plating and were maintained on TSA or Oatmeal agar (Difco, USA) or slopes.

\section{Statistical analysis}

The Shapiro-Wilk normality test was used to determine the distribution of the data. The significance of effects of sample type, inoculum size, incubation time, sample pre-treatments and media choice on viable counts was estimated using Kruskal-Wallis test. The Mann-Whitney $\mathrm{U}$ test was used to identify differences among medians of viable counts obtained with individual pre-treatments and in the absence of treatment.

In order to identify growth media with significant effects on viable counts, we $\log (10)$ transformed the data, performed one-way ANOVA, and calculated the difference between each pair of means using Fisher's least significant difference procedure. 


\section{Phenotypic tests}

The morphological properties of presumably novel isolates were studied microscopically following Gram staining. Gram staining and the determination of catalase and oxidase activities were all performed using standard procedures (Gerhardt et al., 1998). Other biochemical tests were performed by inoculation of API 20 NE, API 20E, API Coryne, API Strep and API 50CH strips (bioMérieux) according to the manufacturer's instructions.

\section{Molecular methods \\ Genomic DNA isolation}

Growth from stationary phase cultures was inoculated aseptically into $150 \mathrm{ml}$ Erlenmeyer flasks containing $10 \mathrm{ml}$ of growth medium and was incubated in a rotary shaker incubator at $22{ }^{\circ} \mathrm{C}$ for 72 hours at $200 \mathrm{rpm}$. Cultures ( $3 \mathrm{ml}$ ) were centrifuged at $12000 \times \mathrm{g}$ for 3 minutes and were resuspended in $500 \mu \mathrm{l}$ of TES buffer $(0.3 \mathrm{M}$ sucrose, $25 \mathrm{mM}$ Tris- $\mathrm{HCl}$ pH 8.0, 25 mM EDTA pH 8.0) supplemented with $50 \mu \mathrm{g} / \mathrm{ml}$ RNase A. Beads ranging in size from 0.1-0.5 $\mu \mathrm{m}$ were added, the mixture was frozen in liquid $\mathrm{N}_{2}$, and the cells were disrupted by bead-beating for five minutes. This suspension was supplemented with $4 \mathrm{mg} / \mathrm{ml}$ of lysozyme and was incubated for 1 hour at $37^{\circ} \mathrm{C}$. Subsequently, $250 \mu \mathrm{l}$ of $2 \%$ sodium dodecyl sulphate was added and the mixture was vortexed for one minute and the resulting lysate was extracted with phenol:chloroform:isoamylalchol (25:42:1). The DNA was precipitated by adding 0.1 volume of $3 \mathrm{M} \mathrm{Na-acetate}(\mathrm{pH}$ 4.8) and 1 volume of isopropanol. After incubating at room temperature for five minutes, the DNA was pelleted, air-dried, resuspended in TE buffer and stored at $-20^{\circ} \mathrm{C}$.

\section{PCR amplification and sequencing}

Genomic DNA of 96 isolates was used as a template in PCR amplifications as described previously (Porca et al., 2012). Sequencing of amplified 16S rRNA genes was performed at Macrogen Inc. (Seoul, Korea) using universal bacterial primers $27 \mathrm{~F}$ and $1492 \mathrm{R}$. Sequences shorter than $750 \mathrm{bp}$ and with average quality values below 20 were removed from the dataset. Upon assembly in BioEdit (Hall, 1999), the final dataset contained 80 sequences. These were compared to databases available from GenBank (http://www.ncbi.nlm.nih.gov, BLASTN algorithm), GREENGENES (http://greengenes.lbl. gov, 'Compare' tool) and EzTaxon (http://eztaxon-e. ezbiocloud.net/, Kim et al., 2012).

\section{Operational taxonomic unit (OTU)-based analysis and phylogenetic analysis}

We used Mothur to group sequences into OTUs (Schloss et al., 2009). The sequences were aligned to Silva-based template alignment (available from http:// www.mothur.org/wiki/Silva_reference_alignment); and the uncorrected pair-wise distances between aligned sequences were calculated. The sequences differing in evolutionary distances by less than 3\% were grouped into OTUs using the furthest neighbour algorithm.

For phylogenetic tree reconstruction, we used MUSCLE (Edgar et al., 2004) to generate an alignment of representative isolate sequences and relevant phylogenetic data. The latter included most similar environmental sequences, most similar validly described species, and major representatives of each taxonomic group detected. Gaps and ambiguously aligned positions were identified using CORE available from T-COFFEE (http://tcoffee.vital-it.ch/ cgi-bin/Tcoffee/ tcoffee_cgi/index.cgi) and subsequently removed from the alignment. This dataset was analysed by maximum likelihood (ML) in MEGA5 (Tamura et al., 2011) by applying a general-time-reversible (GTR) model of sequence evolution and taking among-site variation into account using a four-category discrete approximation of a $\Gamma$ distribution with a portion of invariable sites using MEGA5. ML bootstrap support values were assessed by 1000 bootstrap replications.

The sequences obtained in this study were deposited in GenBank under accession numbers KC978859KC978879.

\section{RESULTS AND DISCUSSION}

\section{Cultivation of cave silver microorganisms on solid media}

We used four sample pre-treatments and seven different growth media in order to initiate the growth of a wide spectrum of prokaryotes that constitute cave silver. Inside Pajsarjeva jama, we sampled areas where individual colour morphotypes covered areas at least one square centimetre in size. We analysed four samples that corresponded to the yellow, pink, grey, and white cave silver morphotypes, respectively. The collected data was not normally distributed (Shapiro-Wilk normality test, W $=0.5, P<0.0001)$ and, therefore, we report the median (Me) and the quartile 1 - quartile 3 values (Q1-Q3).

Upon five weeks of incubation at $30^{\circ} \mathrm{C}$, the median viable counts did not differ if the gathered data were considered with respect to sample colour $(P=0.69$, Kruskal-Wallis test). The median viable counts ranged from $5.8 \times 10^{3}\left(\mathrm{Q} 1-\mathrm{Q} 3=1.20 \times 10^{3}-3.12 \times 10^{4}\right) \mathrm{CFU} / \mathrm{g}$ (greycoloured sample) to $4.2 \times 10^{4}\left(\mathrm{Q} 1-\mathrm{Q} 3=5.80 \times 10^{3}-1.08 \times 10^{5}\right)$ $\mathrm{CFU} / \mathrm{g}$ (pink-coloured sample).

\section{The effect of inoculum size and incubation time on viable counts}

After five weeks of incubation at $30^{\circ} \mathrm{C}$, we did not observe the expected 10 -fold reduction in colony numbers in cultured inoculated with 10-fold fewer bacteria. In fact, the median viable counts obtained in $10^{-3}$ dilutions $\left(\mathrm{Me}=2.50 \times 10^{5} \quad\left(\mathrm{Q} 1-\mathrm{Q} 3=1.10 \times 10^{5}-4.10 \times 10^{5}\right) \quad \mathrm{CFU} / \mathrm{g}\right)$ were a magnitude higher than the counts obtained with $10^{-1}$ diluted samples $\left(\mathrm{Me}=2.25 \times 10^{4} \quad\left(\mathrm{Q} 1-\mathrm{Q} 3=1.75 \times 10^{4}-\right.\right.$ $4.30 \times 10^{4}$ ) CFU/g). This difference was statistically significant (Kruskal Wallis test, $P<0.001$ ) regardless of sample type, sample pre-treatment or growth media used. This phenomenon has been described in other cultivation studies and has been hypothesized to occur due to overcrowding (e.g. Davis et al., 2005) or antibiosis. However, in soil samples, it had no effect on the isolation of members of rarely isolated groups (Davis et al., 2005).

The growth of colonies on media was recorded for five weeks and the first visible colonies were observed at six days after inoculation. The increase in CFU was most prominent during the second and the third week of incubation. Upon the third week of incubation, the total $\mathrm{CFU} / \mathrm{g}$ increased on most media by $0.9 \%$ to $9.0 \%$, 
with exception of SCA and TSA where this increase was $25 \%$ and $56 \%$. The drying of the plates prevented us from measuring growth for any later incubation time points.

\section{The effect of sample pre-treatments on viable counts}

Previous studies indicated that Actinobacteria might be particularly abundant in cave silver colonies from Pajsarjeva jama (Pašić et al., 2010; Porca et al., 2012). In order to increase the numbers and the variety of Actinobacteria in our pure cultures, we applied four different selective pre-treatments. These were previously reported to lead to growth inhibition of some and to stimulate the growth of other actinobacterial genera (wet heat, dry heat), to reduce the spreading of bacteria and fungi (wet heat, phenol) or to increase the number of non-Streptomyces soil actinomycetes (irradiation in a microwave) (e.g. Bredholt et al., 2008; Niyomvong et al., 2012).

The pre-treatments had a significant effect on median viable counts obtained on all counted plates (KruskalWallis test, $P<0.05$ ) (Table 1). The median viable counts were reduced if the samples were irradiated in a microwave, treated with dry heat and phenol, treated with dry heat or treated with wet heat. Compared to untreated samples, only microwave irradiation did not have a statistically significant effect (Mann-Whitney test, $\mathrm{W}=864, P=0.17)$.

We observed no viable counts if the white cave silver sample was irradiated in a microwave. Microwave irradiationisknown toinducegermination of spores of some species of Streptomyces, Nocardia, Streptosporangium, Lentzea, Micromonospora and Micropolyspora (Bulina et al., 1997; Wang et al., 2013). This treatment also reduces total prokaryotic counts (Ferriss, 1984) and has recently been shown to reduce cultivability of some soil isolates affiliated with Actinobacteria, which could be the reason for the apparent absence of CFU. In similar fashion, no viable counts were observed if the pink cave silver sample was treated with dry heat and phenol, a treatment designed to select for actinobacterial genera Micromonospora, Microbispora, Actinoplanes and Streptosporangium (Seong et al., 2001). Indeed, no members of the above listed genera were obtained in pure culture with the notable exception of genus Streptomyces. The ability of these isolates to withstand microwave irradiation and dry heat and phenol treatment is currently under investigation.

\section{The effect of media choice on viable counts}

We based our growth media choice on previous cultivation studies involving cave microorganisms (Jurado et al., 2006; 2008; 2009; Niyomvong et al., 2012). The median viable counts obtained on different media ranged from $1.00 \times 10^{3} \quad\left(\mathrm{Q} 1-\mathrm{Q} 3=6.00 \times 10^{2}-2.00 \times 10^{4}\right)$ observed on MYA to $9.92 \times 10^{4} \quad\left(Q 1-Q 3=3.07 \times 10^{4}-\right.$
$2.70 \times 10^{5}$ ) $\mathrm{CFU} / \mathrm{g}$ observed on TWA medium (Fig. 1). The seven media types used in this study differed in their ability to elicit the formation of colonies (one-way ANOVA, $F=2.98, P<0.05)$. We identified low-nutrient TWA as the only growth medium with significant effect on viable counts (Fisher's least significant difference, $\mathrm{P}<$ 0.05). This was expected given that low-nutrient media favour the growth of slow-growing species, as previously observed in various other environments (e.g. Janssen et al., 2002; Bussmann et al., 2001).

\section{Phylogenetic placement of isolate sequences}

We did a phylogenetic analysis on the representative sequences of OTUs for 80 isolates obtained in this study and relevant environmental sequences present in the GenBank database (Figs. 2, 3). The levels of diversity identified using cultivation dependent and independent approaches were notably different. Actinobacteria made up the dominant group among cultivated strains (47\%) and among the environmental sequences recovered from Pajsarjeva jama cave silver samples (16\%, Pašić et al., 2010). Unfortunately, we could not cultivate Actinobacterial phylotypes that were dominant in environmental 16S rRNA gene libraries (Fig. 2). Instead, the OTUs represented by $16 \mathrm{~S}$ rRNA sequences of isolates C3 (7.5\% of all isolates obtained), F2 (2.5\%), C10 (2.5\%), E4 (3.8\%) and D1 1 (2.5\%) were $\geq 99 \%$ similar to $16 \mathrm{~S}$ rRNA sequences of Rhodococcus wratislaviensis, Rhodococcus erythropolis, Kocuria kristinae, Microbacterium paraoxidans, and Agrococcus citreus, respectively. The OTUs represented by isolates A11 (16.3\%), D8 (2.5\%),

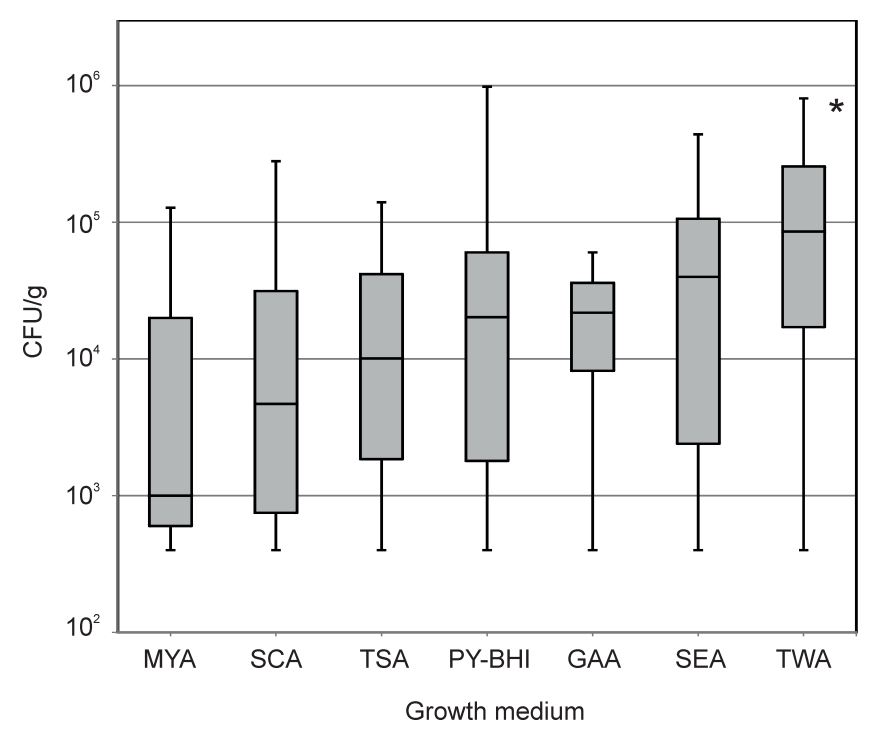

Fig. 1. Distribution of median viable counts on plates inoculated with cave silver samples upon five weeks of incubation at $30^{\circ} \mathrm{C}$ with respect to growth medium. The box-plots show minimum, maximum, the 25 and 75 percentile and median. The growth medium with significant effect on viable counts (Fisher's least significant difference, $\mathrm{P}<0.05)$ is indicated by an asterisk.

Table 1. Total viable counts (CFU/g) obtained from pretreated cave silver samples.

\begin{tabular}{|l|c|c|c|c|c|c|}
\hline Sample & $\begin{array}{c}\text { Wet heat } \\
(\mathrm{a})\end{array}$ & $\begin{array}{c}\text { Dry heat } \\
(\mathrm{b})\end{array}$ & $\begin{array}{c}\text { Dry heat and phenol } \\
(\mathrm{c})\end{array}$ & $\begin{array}{c}\text { Electromagnetic wave } \\
(\mathrm{d})\end{array}$ & $\begin{array}{c}\text { No treatment } \\
(\mathrm{e})\end{array}$ & $\begin{array}{c}\text { Total number of } \\
\text { isolates }\end{array}$ \\
\hline Yellow & $1.4 \times 10^{3}$ & $2.0 \times 10^{2}$ & $2.0 \times 10^{4}$ & $2.0 \times 10^{6}$ & $5.9 \times 10^{6}$ & 12 \\
\hline Gray & $2.2 \times 10^{4}$ & $2.0 \times 10^{4}$ & $2.0 \times 10^{2}$ & $2.1 \times 10^{6}$ & $7.7 \times 10^{6}$ & 29 \\
\hline White & $4.4 \times 10^{3}$ & $2.0 \times 10^{2}$ & $5.6 \times 10^{4}$ & $\mathrm{ND}$ & $2.7 \times 10^{7}$ & 15 \\
\hline Pink & $2.0 \times 10^{4}$ & $4.0 \times 10^{4}$ & $\mathrm{ND}$ & $5.3 \times 10^{6}$ & $1.9 \times 10^{7}$ & 24 \\
\hline
\end{tabular}




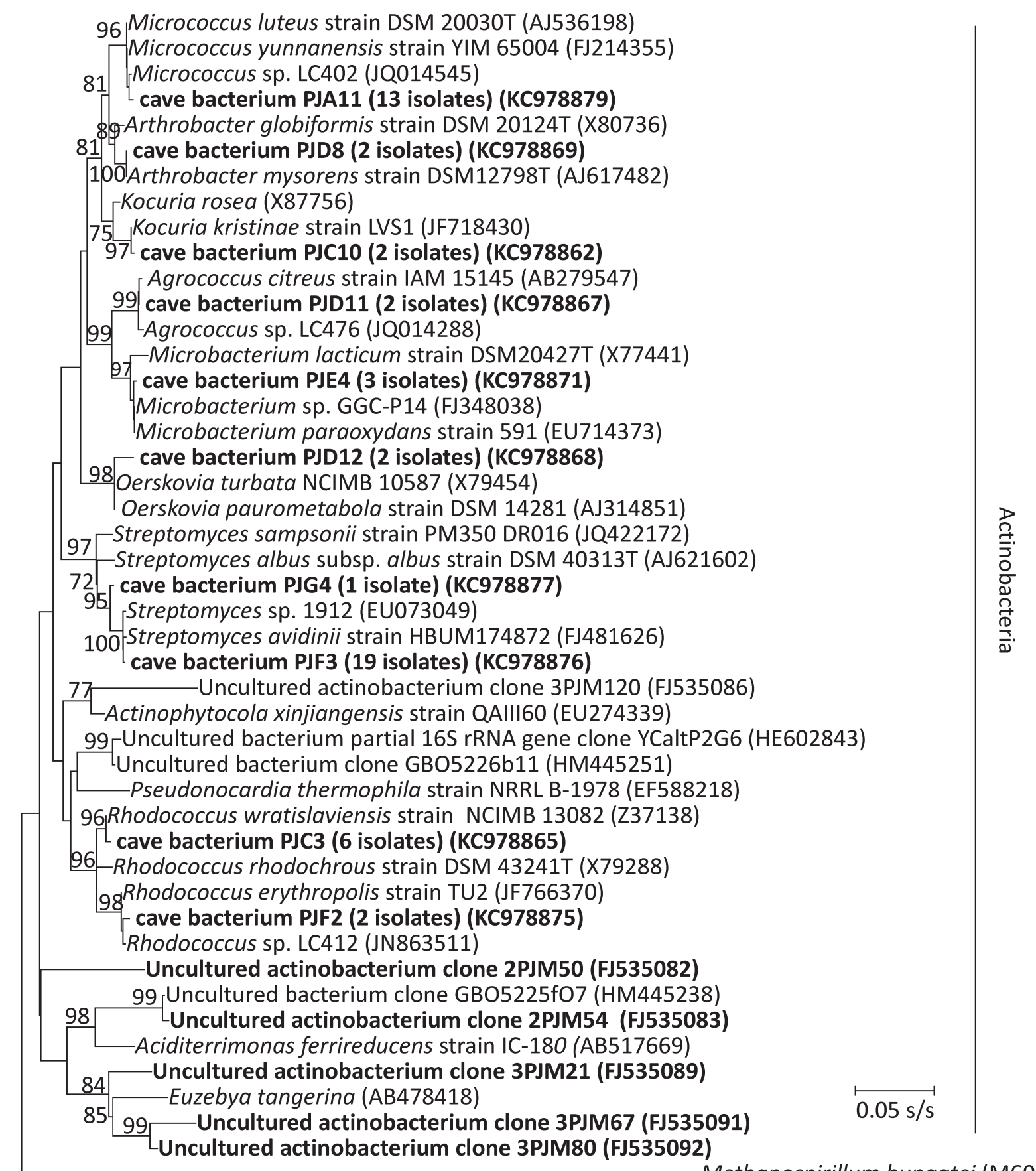

Methanospirillum hungatei (M6088

Fig. 2. ML tree showing the phylogenetic position of OTU representatives (prefix 'cave bacterium PJ') belonging to Actinobacteria. Numbers at nodes $(>75 \%)$ indicate percentages of 1000 bootstrap resamplings. Sequences with prefix 'uncultured actinobacterium clone PJM' originate from a previous study (Pašić et al., 2010).

D12 (2.5\%), G4 (1.3\%) and F3 (23.8\%) shared 95\%-97\% sequence identity with validly described species and likely represent novel taxa. Their phenotypic characteristics are presented in Table 2.

In similar fashion, the environmental 16S rRNA sequences affiliated with Proteobacteria differed from those obtained through the cultivation approach (Fig. 3). While environmental 16S rRNA sequences were related to Chromatiales (23.4\%) and Xanthomonadales (7.9\%), the cultivated taxa (OTU representatives A9 (1.3\% of isolates obtained in this study), C11 (7.5\%) and C1 (6.3\%)) represented novel phylotypes within genera Pseudomonas and Lysobacter. Isolate sequences affiliated with Alphaproteobacteria shared $\leq 97 \%$ sequence identity with known species of genera Sphingomonas (B3, 2.5\%), Bosea (C5, 1.3\%) and Agrobacterium (A3, 6.3\%). We further cultivated members of Firmicutes, a group that was not found in Pajsarjeva jama using a cultivationindependent approach. Their 16S rRNA sequences were not closely related (95\%-97\% sequence identity) to validly described species of genera Paenibacillus (E2, 5\%), Bacillus (E7, 1.3\%; H9, 1.3\%) and Aerococcus (F10, $1.3 \%)$. Phenotypic characteristics of the presumably novel taxa listed above are presented in Table 2.

The majority of cave isolates reported here were obtained on multiple media. Microbacterium, Micrococcus, Oerskovia, Paenibacillus, Pseudomonas, Rhodococcus, Streptomyces, Agrobacterium, Lysobacter and Arthrobacter species were obtained from PY-BHI, SCA, SEA, TSA and TWA. A group of isolates belonging to genus Pseudomonas was obtained on GAA and MYA media. Bacillus species were obtained only on TSA and SCA. Finally, isolates belonging to the genera Bosea, Kocuria and Sphingomonas were isolated only on TWA 
Herzog-Velikonja, Tkavc, and Pašić

Table 2. Phenotypic features of presumably novel isolates detected in this study.

\begin{tabular}{|c|c|c|c|c|c|c|c|c|}
\hline Isolate name & PJC1 & PJA9 & PJC11 & PJE2 & PJB3 & PJC5 & PJA3 & PJA11 \\
\hline $\begin{array}{l}\text { Proposed } \\
\text { phylogenetic } \\
\text { affiliation }\end{array}$ & Lysobacter sp. & Pseudomonas sp. & Pseudomonas sp. & Paenibacillus sp. & $\begin{array}{l}\text { Sphingomonas } \\
\text { sp. }\end{array}$ & Bosea sp & Agrobacterium sp. & Micrococcus sp. \\
\hline $\begin{array}{l}\text { Colony } \\
\text { pigmentation on } \\
\text { TSA medium }\end{array}$ & Pale-yellow & White & White & White & White & Cream & White & Yellow \\
\hline Cell shape & Rods & Rods & Rods & Rods & Rods & $\begin{array}{l}\text { Rods, straight to } \\
\text { curved }\end{array}$ & Rods & Cocci \\
\hline Gram stain & Negative & Negative & Negative & Positive & Negative & Negative & Negative & Positive \\
\hline Oxidase & Negative & Positive & Positive & Positive & Negative & Positive & Positive & Positive \\
\hline Catalase & Positive & Positive & Positive & Negative & Negative & Positive & Positive & Negative \\
\hline \multicolumn{9}{|c|}{ Biochemical characteristics (API 20NE) } \\
\hline & $\begin{array}{l}\text { Glucose } \\
\text { fermentation }\end{array}$ & $\begin{array}{l}\text { Glucose } \\
\text { fermentation }\end{array}$ & Esculin hydrolysis & $\begin{array}{l}\text { Reduction of } \\
\text { nitrates to nitrites }\end{array}$ & Esculin hydrolysis & $\begin{array}{l}\text { Reduction } \\
\text { of nitrates to } \\
\text { nitrogen }\end{array}$ & Esculin hydrolysis & $\begin{array}{l}\text { Glucose } \\
\text { fermentation }\end{array}$ \\
\hline & Gelatin hydrolysis & Arginin hydrolysis & & Urea hydrolysis e & & Indole production & $\beta$-galactosidase & Gelatin hydrolysis \\
\hline & Esculin hydrolysis & Urea hydrolysis & & Esculin hydrolysis & & & & \\
\hline \multicolumn{2}{|c|}{ Assimilation of (API 20NE) } & & & $\beta$-galactosidase & & & & \\
\hline & D-glucose & D-glucose & D-glucose & D-mannitol & D-glucose & D-mannose & D-glucose & D-glucose \\
\hline & & L-arabinose & L-arabinose & $\begin{array}{l}\mathrm{N} \text {-acetyl- } \\
\text { glucosamine }\end{array}$ & L-arabinose & $\begin{array}{l}\text { Potassium } \\
\text { gluconate }\end{array}$ & L-arabinose & D-maltose \\
\hline & & D-mannose & D-mannose & D-mannitol & & & D-mannose & Phenylacetic acid \\
\hline & & D-mannitol & D-mannitol & $\begin{array}{l}\text { Potassium } \\
\text { gluconate }\end{array}$ & & & D-mannitol & \\
\hline & & $\begin{array}{l}\text { Potassium } \\
\text { gluconate }\end{array}$ & $\begin{array}{l}\mathrm{N} \text {-acetyl- } \\
\text { glucosamine }\end{array}$ & Adipic acid & & & $\begin{array}{l}\mathrm{N} \text {-acetyl- } \\
\text { glucosamine }\end{array}$ & \\
\hline & & Capric acid & $\begin{array}{l}\text { potassium } \\
\text { gluconate }\end{array}$ & Malic acid & & & D-maltose & \\
\hline & & Adipic acid & Capric acid & Trisodium citrate & & & Malic acid & \\
\hline & & Malic acid & Malic acid & & & & & \\
\hline & & Trisodium citrate & Trisodium citrate & & & & & \\
\hline \multicolumn{9}{|c|}{ Acid production from (API 50CH) } \\
\hline & Glycerol & Galactose & D-glucose & Glycerol & Glycerol & Ribose & Ribose & Galactose \\
\hline & Ribose & D-glucose & Esculin & Erythritol & Erythritol & Esculin & Amidon & D-glucose \\
\hline & Galactose & D-fructose & & L-arabinose & L-arabinose & & $\beta$-gentiobiose & D-fructose \\
\hline & D-glucose & D-mannose & & Ribose & Ribose & & D-fucose & D-mannose \\
\hline & D-fructose & Maltose & & D-xylose & D-xylose & & L-fucose & $\begin{array}{l}\mathrm{N} \text {-acetyl } \\
\text { glucosamine }\end{array}$ \\
\hline & D-mannose & Lactose & & Galactose & Adonitol & & Esculin & Maltose \\
\hline & Mannitol & Saccharose & & D-glucose & $\beta$ methyl-xyloside & & & Lactose \\
\hline & Sorbitol & Trehalose & & D-fructose & $\beta$ methyl-xyloside & & & Saccharose \\
\hline & Esculin & & & D-mannose & Galactose & & & Trehalose \\
\hline & Maltose & & & $\begin{array}{l}\mathrm{N} \text {-acetyl } \\
\text { glucosamine }\end{array}$ & D-glucose & & & D-tyranose \\
\hline & Lactose & & & Arbutine & D-fructose & & & D-tyranose \\
\hline & Saccharose & & & Esculin & D-mannose & & & Esculin \\
\hline & Trehalose & & & Salicine & L-sorbose & & & \\
\hline & Gluconate & & & Maltose & Sorbitol & & & \\
\hline & Esculin & & & Lactose & $\begin{array}{l}\mathrm{N} \text {-acetyl } \\
\text { glucosamine }\end{array}$ & & & \\
\hline & & & & Amidon & Amygdaline & & & \\
\hline & & & & Glycogene & Cellobiose & & & \\
\hline & & & & $\beta$-gentiobiose & Lactose & & & \\
\hline & & & & Esculin & Maltose & & & \\
\hline & & & & & Saccharose & & & \\
\hline & & & & & Trehalose & & & \\
\hline & & & & & Esculin & & & \\
\hline
\end{tabular}

medium and isolates related to Agrococcus only on SEA. The pre-treatments did not increase the diversity of isolates obtained in pure culture. In fact, only a single isolate was obtained exclusively from a pre-treated sample (microwave irradiation, a non-Streptomyces actinomycete). Some differences in diversity of pure cultures were observed if the isolates were grouped with respect to sample colour (Table 3). Twelve isolates originated from the yellow sample, 29 from grey, 15 from white and 24 from a pink coloured sample. Common to all samples were the abundant groups belonging to the genera Agrobacterium and Streptomyces, while isolates belonging to Rhodococcus, Pseudomonas, Paenibacillus, Micrococcus and Arthrobacter were present in at least 
Cultivable diversity of cave wall microbial colonies

Table 2 (continued). Phenotypic features of presumably novel isolates detected in this study.

\begin{tabular}{|c|c|c|c|c|c|c|c|}
\hline Isolate name & PJH9 & PJE7 & PJD12 & PJD8 & PJF3 & PJG4 & PJF10 \\
\hline $\begin{array}{l}\text { Proposed phylogenetic } \\
\text { affiliation }\end{array}$ & Bacillus sp. & Bacillus sp. & Oerskovia sp. & Arthrobacter sp. & Streptomyces sp. & Streptomyces sp. & Aerococcus sp. \\
\hline $\begin{array}{l}\text { Colony pigmentation on } \\
\text { TSA medium }\end{array}$ & White & White & Pale yellow & White & Cream & White & White \\
\hline Cell shape & Rods & Rods & Branched filaments & Rods to cocci & Filaments & Filaments & Cocci \\
\hline Gram stain & Positive & Positive & & Positive & Positive & Positive & Positive \\
\hline Oxidase & Positive & Positive & Positive & Positive & Positive & Positive & Negative \\
\hline Catalase & Negative & Positive & Negative & Positive & Positive & Negative & Negative \\
\hline \multicolumn{3}{|c|}{ Biochemical characteristics (API 20E) } & \multicolumn{2}{|l|}{ (API Coryne) } & & & (API Strep) \\
\hline & $\begin{array}{l}\text { Fermentation of } \\
\text { D-glucose }\end{array}$ & Citrate utilisation & Nitrate reduction & Nitrate reduction & $\begin{array}{l}\text { Alkaline } \\
\text { phosphatase }\end{array}$ & $\begin{array}{l}\text { Alkaline } \\
\text { phosphatase }\end{array}$ & $\begin{array}{l}\text { Pyrolidonyl } \\
\text { arylamidase }\end{array}$ \\
\hline & $\begin{array}{l}\text { Fermentation of } \\
\text { arabinose }\end{array}$ & Urea hydrolysis & $\beta$-galactosidase & $\begin{array}{l}\text { Pyrolidonyl } \\
\text { arylamidase }\end{array}$ & $\beta$-galactosidase & $\beta$-galactosidase & $\begin{array}{l}\text { Acidification of } \\
\text { lactose }\end{array}$ \\
\hline & & $\begin{array}{l}\text { Fermentation of } \\
\text { D-glucose }\end{array}$ & a-glucosidase & $\begin{array}{l}\text { Alkaline } \\
\text { phosphatase }\end{array}$ & $\begin{array}{l}\mathrm{N} \text {-acetyl } \\
\beta \text {-glucosaminidase }\end{array}$ & $\begin{array}{l}\mathrm{N} \text {-acetyl } \\
\beta \text {-glucosaminidase }\end{array}$ & $\begin{array}{l}\text { Acidification of } \\
\text { trehalose }\end{array}$ \\
\hline & & $\begin{array}{l}\text { Fermentation of } \\
\text { D-mannose }\end{array}$ & $\begin{array}{l}\mathrm{N} \text {-acetyl } \\
\beta \text {-glucosaminidase }\end{array}$ & $\beta$-galactosidase & $\begin{array}{l}\text { Fermentation of } \\
\text { D-mannitol }\end{array}$ & Gelatin hydrolysis & $\begin{array}{l}\text { Acidification of } \\
\text { inuline }\end{array}$ \\
\hline & & $\begin{array}{l}\text { Fermentation of } \\
\text { saccharose }\end{array}$ & $\beta$-glucosidase & Gelatin hydrolysis & $\begin{array}{l}\text { Fermentation of } \\
\text { D-maltose }\end{array}$ & $\begin{array}{l}\text { Fermentation of } \\
\text { D-maltose }\end{array}$ & a-haemolysis \\
\hline & & & Gelatin hydrolysis & $\begin{array}{l}\text { Fermentation of } \\
\text { D-glucose }\end{array}$ & & & \\
\hline & & & $\begin{array}{l}\text { Fermentation of } \\
\text { D-glucose }\end{array}$ & $\begin{array}{l}\text { Fermentation of } \\
\text { ribose }\end{array}$ & & & \\
\hline & & & $\begin{array}{l}\text { Fermentation of } \\
\text { ribose }\end{array}$ & $\begin{array}{l}\text { Fermentation of } \\
\text { xylose }\end{array}$ & & & \\
\hline & & & $\begin{array}{l}\text { Fermentation of } \\
\text { xylose }\end{array}$ & $\begin{array}{l}\text { Fermentation of } \\
\text { maltose }\end{array}$ & & & \\
\hline & & & $\begin{array}{l}\text { Fermentation of } \\
\text { maltose }\end{array}$ & $\begin{array}{l}\text { Fermentation of } \\
\text { mannose }\end{array}$ & & & \\
\hline & & & & $\begin{array}{l}\text { Fermentation of } \\
\text { saccharose }\end{array}$ & & & \\
\hline \multicolumn{8}{|c|}{ Acid production from (API 50CH) } \\
\hline & Glycerol & L-arabinose & Glycerol & Glycerol & Glycerol & Rhamnose & Ribose \\
\hline & D-glucose & Ribose & Erythritol & Erythritol & L-xylose & Esculin & Galactose \\
\hline & D-fructose & Galactose & L-arabinose & Ribose & Adonitol & Maltose & D-glucose \\
\hline & Mannitol & D-glucose & D-arabinose & D-xylose & D-mannose & Trehalose & D-fructose \\
\hline & $\begin{array}{l}\mathrm{N} \text {-acetyl } \\
\text { glucosamine }\end{array}$ & D-fructose & Ribose & L-xylose & L-sorbose & Melezitose & D-mannose \\
\hline & Maltose & D-fructose & D-xylose & Adonitol & Mannitol & D-tagatose & Salicine \\
\hline & Saccharose & Salicine & Galactose & $\beta$-methyl xyloside & $\begin{array}{l}\text { a methyl-D- } \\
\text { mannoside }\end{array}$ & Gluconate & Cellobiose \\
\hline & Trehalose & Cellobiose & D-glucose & & $\begin{array}{l}\mathrm{N} \text {-acetyl } \\
\text { glucosamine }\end{array}$ & 5 ceto-gluconate & Maltose \\
\hline & D-raffinose & Maltose & D-fructose & & Arbutine & & Lactose \\
\hline & D-turanose & Lactose & D-mannose & & Salicine & & Saccharose \\
\hline & Esculin & Saccharose & $\begin{array}{l}\mathrm{N} \text {-acetyl } \\
\text { glucosamine }\end{array}$ & & Cellobiose & & Trehalose \\
\hline & & Trehalose & Amygdaline & & Maltose & & Inuline \\
\hline & & $\beta$-gentiobiose & Arbutine & & Melibiose & & \\
\hline & & D-fucose & Esculin & & D-raffinose & & \\
\hline & & L-fucose & Cellobiose & & D-turanose & & \\
\hline & & 2 ceto-gluconate & Maltose & & D-arabitol & & \\
\hline & & 2 ceto-gluconate & Saccharose & & Gluconate & & \\
\hline & & & Trehalose & & 5 ceto-gluconate & & \\
\hline & & & Amidone & & & & \\
\hline & & & Glycogene & & & & \\
\hline & & & Xylitol & & & & \\
\hline & & & $\beta$-gentiobiose & & & & \\
\hline & & & D-turanose & & & & \\
\hline & & & D-lyxose & & & & \\
\hline & & & Gluconate & & & & \\
\hline & & & Esculin & & & & \\
\hline
\end{tabular}




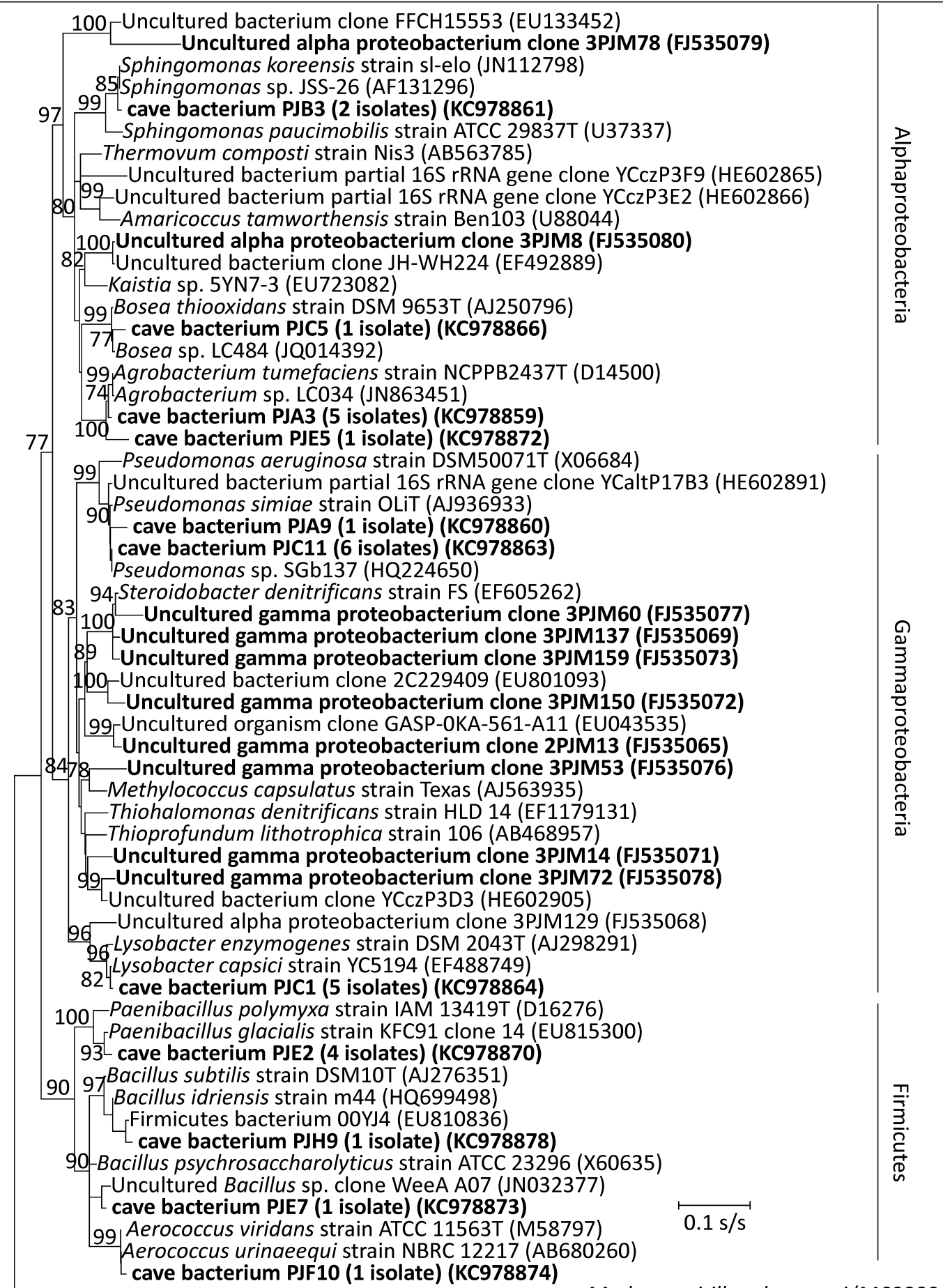

Fig. 3. ML tree showing the phylogenetic position of OTU representatives (prefix 'cave bacterium PJ') belonging to Proteobacteria and Firmicutes. Numbers at nodes $(>75 \%)$ indicate percentages of 1000 bootstrap resamplings. Sequences with prefixes 'uncultured gamma proteobacterium clone PJM' and 'uncultured alpha proteobacterium clone PJM' originate from a previous study (Pašić et al., 2010).

two different samples. The remaining isolates were sample-specific and represented a minor portion of diversity encountered.

In 2010, Jurado et al. reported on the widespread occurrence of pathogenic and opportunistic microorganisms in caves. The caves were found to support a number of pathogenic bacteria that included species of Micrococcus, Pseudomonas, Bacillus, Stentrophomonas and Aureimonas. All these were found to cause infections of the respiratory organs and eyes in new-borns, children and elderly (Jurado et al., 2010). More recently, Bhullar et al. (2012) reported that cave microbes are often highly resistant to commercial antibiotics, despite their long-term isolation from the surface. The results of this study add to the growing understanding of potential health risks associated with cave tourism. A number of bacterial isolates obtained in this study are affiliated with pathogenic bacteria, namely with Bacillus idriensis, Pseudomonas simiae, Kocuria kristinae, Microbacterium paraoxydans, and Rhodococcus erythropolis. All these species were reported to cause bacteraemia in humans and apes (Laffineur et al., 2003; Ma et al., 2005; Ko et al., 2006; Vela et al., 2006; Baba et al., 2009).

\section{On the source of cave microbes}

A major goal of this study was to contribute to the current knowledge on the source of cave microbes. To this aim, we compared our sequences to a subset of $1230116 \mathrm{~S}$ rRNA sequences that originated from cave environments and that were present in GenBank 
database on January 29th, 2013 (Table 3). We found that isolate and environmental 16S rRNA sequences $\geq 97 \%$ similar to OTUs sequences recovered in this study were reported from the walls and ceilings of a number of subterranean environments that differ widely in geology, e.g. from Pajsarjeva jama in Slovenia (Porca et al., 2012) formed though dissolution of limestone by carbonic acid, from Lechuguilla cave, formed by dissolution of limestone by sulfuric acid (Johnston et al., 2011), and from lava tubes formed by volcanic activity (Northup et al., 2011). Furthermore, members of genera Bacillus, Micrococcus,
Arthrobacter, Paenibacillus, Streptomyces, Oerskovia, and Microbacterium were recently reported in an aerobiological study, which examined human-induced environmental disturbances in Ardales cave in Spain (Fernandez-Cortes et al., 2011). This study concluded that cave microbes are likely dispersed as spores or attached to particles through action of wind and turbulence or through the impact of splashes of cave water droplets (Fernandez-Cortes et al., 2011).

It is interesting that the representative $16 \mathrm{~S}$ rRNA sequences of OTUs affiliated with Rhodococcus,

Table 3. The similarities of 16S rRNA sequences of OTU representatives detected in this study to 16S rRNA sequences present in GenBank. Presumably novel taxa ( $\leq 97 \%$ sequence identity to cultivated species) are indicated in bold.

\begin{tabular}{|c|c|c|c|c|c|c|c|}
\hline Isolate name & $\begin{array}{l}\text { Isolate obtained from } \\
\text { sample* }\end{array}$ & $\begin{array}{l}\text { Description of } \\
\text { the most similar } \\
\text { sequence }\end{array}$ & $\begin{array}{c}\text { GenBank accession } \\
\text { number }\end{array}$ & $\%$ Identity & Query coverage \% & $\begin{array}{l}\text { Most similar } \\
\text { sequence origin }\end{array}$ & GenBank reference \\
\hline PJ A3 & Y, G, W, P & $\begin{array}{c}\text { Agrobacterium sp. } \\
\text { LC034 }\end{array}$ & JN863451 & 98.8 & 97.0 & $\begin{array}{c}\text { Lechuguilla Cave, } \\
\text { USA }\end{array}$ & Johnston et al., 2012 \\
\hline PJ A9 & $P$ & $\begin{array}{l}\text { Pseudomonas } \\
\text { fluorescens R124 }\end{array}$ & M001561 & 98.3 & 85.5 & $\begin{array}{c}\text { Orthoquartzite cave } \\
\text { surface }\end{array}$ & $\begin{array}{l}\text { Barton et al., 2012, } \\
\text { unpublished }\end{array}$ \\
\hline PJ A11 & G, W, P & $\begin{array}{l}\text { Micrococcus sp. } \\
\text { LC402 }\end{array}$ & JQ014545 & 99.2 & 96.5 & $\begin{array}{c}\text { Lechuguilla Cave, } \\
\text { USA }\end{array}$ & Johnston et al., 2012 \\
\hline PJ B3 & G & $\begin{array}{l}\text { Uncultured bacterium } \\
\text { clone CC01f45b11 }\end{array}$ & JQ675472 & 97.6 & 100 & $\begin{array}{l}\text { Carlsbad Caverns, } \\
\text { New Mexico Room, } \\
\text { USA, water sample }\end{array}$ & $\begin{array}{c}\text { Hughes et al., 2012, } \\
\text { unpublished }\end{array}$ \\
\hline PJ C1 & G & $\begin{array}{l}\text { Uncultured bacterium } \\
\text { clone GA21498a09 }\end{array}$ & JN607002 & 97.5 & 97.9 & $\begin{array}{c}\text { White microbial mat } \\
\text { from lava tube wall, } \\
\text { Gruta das Agulhas } \\
\text {, Terceira, Azores, } \\
\text { Portugal }\end{array}$ & Northup et al., 2011 \\
\hline PJ C10 & Y & $\begin{array}{c}\text { Kocuria rosea strain } \\
\text { MM1-1 }\end{array}$ & JX144942 & 97.0 & 98.0 & $\begin{array}{l}\text { Biofilm in Mawsmai } \\
\text { cave, India }\end{array}$ & $\begin{array}{l}\text { Banerjee and Joshi, } \\
2013\end{array}$ \\
\hline PJ C11 & $\mathrm{Y}, \mathrm{P}$ & $\begin{array}{l}\text { Uncultured bacterium } \\
\text { clone YCaltP17B3 }\end{array}$ & HE602891 & 98.9 & 100 & $\begin{array}{l}\text { Macroscopic yellow } \\
\text { colony cave wall } \\
\text { sample from Altamira } \\
\text { cave, Spain }\end{array}$ & Porca et al., 2012 \\
\hline PJ C3 & Y, G, P & $\begin{array}{c}\text { Uncultured } \\
\text { Rhodococcus sp. } \\
\text { clone EC34BH03 }\end{array}$ & JN032369 & 96.6 & 97.1 & Cave & $\begin{array}{c}\text { Johnston et al., } \\
2012\end{array}$ \\
\hline PJ C5 & $P$ & Bosea sp. LC484 & JQ014392 & 98.1 & 99.0 & $\begin{array}{c}\text { Lechuguilla Cave, } \\
\text { USA }\end{array}$ & Johnston et al., 2012 \\
\hline PJ D11 & G & $\begin{array}{l}\text { Agrococcus sp. } \\
\text { LC476 }\end{array}$ & JQ014288 & 99.0 & 93.8 & $\begin{array}{c}\text { Lechuguilla Cave, } \\
\text { USA }\end{array}$ & Johnston et al., 2012 \\
\hline PJ D12 & $P$ & $\begin{array}{c}\text { Oerskovia } \\
\text { paurometabola strain } \\
\text { 0410ARD15N_4 }\end{array}$ & FR848425 & 98.8 & 96.3 & Air from a cave & $\begin{array}{c}\text { Fernandez-Cortes et } \\
\text { al., } 2011\end{array}$ \\
\hline PJ D8 & $\mathrm{G}, \mathrm{P}$ & $\begin{array}{l}\text { Arthrobacter } \\
\text { mysorens strain } \\
\text { DSM 12798T }\end{array}$ & AJ617482 & 98.2 & 92.3 & Alpine ice cave & $\begin{array}{c}\text { Margesin et al. 2003, } \\
\text { unpublished }\end{array}$ \\
\hline PJ E2 & Y, G & $\begin{array}{l}\text { Uncultured } \\
\text { bacterium clone } \\
\text { GTM1017c09 }\end{array}$ & JN600577 & 94.9 & 92.3 & $\begin{array}{c}\text { Tan microbial mat } \\
\text { from lava tube } \\
\text { wall, Gruta Terra } \\
\text { Mole, Terceira, } \\
\text { Azores,Portugal }\end{array}$ & Northup et al., 2011 \\
\hline PJ E4 & $P$ & $\begin{array}{l}\text { Microbacterium sp. } \\
\text { GGC-P14 }\end{array}$ & FJ348038 & 99.3 & 95.5 & $\begin{array}{c}\text { Cave coralloid } \\
\text { speleothem, Wayne } \\
\text { county, Kentucky, } \\
\text { USA }\end{array}$ & Banks et al., 2010 \\
\hline PJ E5 & $\mathbf{G}$ & $\begin{array}{c}\text { Agrobacterium sp. } \\
\text { LC034 }\end{array}$ & JN863451 & 95.9 & 96.8 & $\begin{array}{c}\text { Lechuguilla Cave, } \\
\text { USA }\end{array}$ & $\begin{array}{l}\text { Johnston et al., } \\
\quad 2012\end{array}$ \\
\hline PJ E7 & Y & $\begin{array}{l}\text { Uncultured Bacillus } \\
\text { sp. clone WeeA_A07 }\end{array}$ & JN032377 & 98.4 & 95.3 & Cave & Johnston et al., 2012 \\
\hline PJ F10 & $\mathbf{P}$ & $\begin{array}{c}\text { Bacillus sp. GGC- } \\
\text { P5A1 }\end{array}$ & FJ348046 & 92.0 & 93.0 & $\begin{array}{c}\text { Cave coralloid } \\
\text { speleothem, Wayne } \\
\text { county, Kentucky, } \\
\text { USA }\end{array}$ & Banks et al., 2010 \\
\hline PJ F2 & $\mathrm{Y}, \mathrm{G}$ & $\begin{array}{c}\text { Rhodococcus sp. } \\
\text { LC412 }\end{array}$ & JN863511 & 99.5 & 90.5 & $\begin{array}{c}\text { Lechuguilla Cave, } \\
\text { USA }\end{array}$ & Johnston et al., 2012 \\
\hline PJ F3 & $\mathrm{Y}, \mathrm{G}, \mathrm{W}, \mathrm{P}$ & $\begin{array}{l}\text { Streptomyces sp. } \\
\quad \text { strain } 1912\end{array}$ & EU073049 & 99.6 & 95.9 & $\begin{array}{c}\text { Balatini cave, } \\
\text { Derebucak, Konya, } \\
\text { Turkey }\end{array}$ & $\begin{array}{l}\text { Isik et al., 2007, } \\
\text { unpublished }\end{array}$ \\
\hline PJ G4 & $\mathbf{Y}$ & $\begin{array}{l}\text { Streptomyces } \\
\text { sampsonii strain } \\
\text { PM350_DR016 }\end{array}$ & JQ422172 & 96.8 & 97.7 & $\begin{array}{c}\text { Helmcken Falls } \\
\text { Cave, Wells Gray } \\
\text { Provincial Park, BC, } \\
\text { Canada }\end{array}$ & $\begin{array}{l}\text { Cheeptham et al., } \\
2013\end{array}$ \\
\hline PJ H9 & W & $\begin{array}{c}\text { Firmicutes bacterium } \\
\text { 00YJ4 }\end{array}$ & EU810836 & 99.2 & $98.6 \mathrm{~s}$ & $\begin{array}{l}\text { Cave of Doña } \\
\text { Trinidad, Ardales, } \\
\text { Malaga, Spain }\end{array}$ & $\begin{array}{c}\text { Stomeo et al., } 2008 \\
\text { unpublished }\end{array}$ \\
\hline
\end{tabular}

*Abbreviations $\mathrm{Y}, \mathrm{W}, \mathrm{G}$ and $\mathrm{P}$ correspond to yellow, white, grey and pink cave microbial colony sample. 
Paenibacillus, Agrobacterium, Aerococcus and Streptomyces $(16.4 \%$ of isolates) corresponded to organisms more distantly related (92.0-96.8\% sequence identity) to cave organisms. However, these organisms were related ( $\geq 97 \%$ sequence identity) to freshwater (Rhodococcus, Paenibacillus), soil (Agrobacterium, Streptomyces), or host-associated (Aerococcus) bacteria.

\section{CONCLUSION}

We isolated 80 morphologically different bacterial isolates from samples of microbial colonies that develop on the walls of Pajsarjeva jama in Slovenia. Viable counts increased with a decrease in inoculum size and were reduced if samples were exposed to pretreatments. All growth media yielded viable counts, however these were highest on a low-nutrient TWA medium. We obtained 21 species-level OTU and found Agrobacterium and Streptomyces in all samples. We found a number of isolates was unrelated to validly described species. Although the obtained isolates likely represent a minor portion of diversity, they appear to be widespread in subterranean environments, judging from the distribution of highly related 16S rRNA gene sequences.

\section{ACKNOWLEDGEMENTS}

This study was supported by the Slovenian Research Agency research program P1-0198. We thank Sandra Cundrič who contributed to isolation and maintenance of microorganisms as an undergraduate student. We are grateful to Marijan Govedič and Andrej Blejec for advice and helpful discussions regarding statistical analysis and to George Liechti for critical reading of the manuscript.

\section{REFERENCES}

Baba H., Nada T., Okhusu K., Ezaki T., Hasegawa Y. \& Paterson D.L., 2009 - First case of bloodstram infection caused by Rhodococcus erythropolis. Journal of Clinical Microbiology, 47: 2667-2669.

http://dx.doi.org/10.1128/JCM.00294-09

Banerjee S. \& Joshi S.R., 2013 - Insights into cave architecture and the role of bacterial biofilm. Proceedings of the National Academy of Sciences, India Section B: Biological Sciences: 1-14.

Banks E.D., Taylor, N.M., Gulley J., Lubbers B.R., Giarrizo J.G., Bullen H.A., Hoehler T.M. \& Barton H.A., 2010 - Bacterial calcium carbonate precipitation in cave environments: a function of calcium homeostasis. Geomicrobiology Journal, 27: 444-454.

http:/ / dx.doi.org/ 10.1080/01490450903485136

Barton H.A. \& Jurado V., 2007 - What's up down there? Microbial diversity in caves. Microbe, 2: 132-138.

Bhullar K., Waglechner N., Pawlowski A., Koteva K., Banks E.D., Johnston M.D., Barton H.A. \& Wright G.A., 2012 - Antibiotic resistance is prevalent in an isolated cave microbiome. PloS ONE, 7: e34953. http://dx.doi.org/10.1371/journal.pone.0034953

Bredholt H. \& Fjaervik E., 2008 - Actinomycetes from sediments in the Trondheim Fjord, Norway: Diversity and biological activity. Marine Drugs, 6: 12-24. http://dx.doi.org/10.3390/md6010012
Bulina T.I., Alferova I.V. \& Terekhova L.P., 1997- A novel approach to isolation of actinomycetes involvin irradiation of soil samples with microwaves. Microbiology, 66: 231-234.

Burnham K.P. \& Overton W.S., 1978 - Estimation of the size of a closed population when capture probabilities vary among animals. Biometrika, 65: 625-633.

http://dx.doi.org/10.1093/biomet/65.3.625

Bussmann I., Philipp B. \& Schink B., 2001 - Factors influencing the cultivability of lake water bacteria. Journal of Microbiological Methods, 47: 41-50. http://dx.doi.org/10.1016/S0167-7012(01)00289-5

Cheeptham N., Sadoway T., Rule D., Watson K., Moote P., Soliman L., Azad N., Donkor K. \& Horne D., 2013 - Cure from the cave: volcanic cave actinomycetes and their potential in drug discovery. International Journal of Speleology, 42: 35-47.

http://dx.doi.org/10.5038/1827-806X.42.1.5

Cuezva S., Fernandez-Cortes A., Porca E., Pašić L., Jurado V., Hernandez-Marine M., Serrano-Ortiz P., Hermosin B., Cañaveras J.C., Sanchez-Moral S. \& Saiz-Jimenez C. (2012). The biogeochemical role of Actinobacteria in Altamira Cave, Spain. FEMS Microbiology Ecology, 81: 281-290. http://dx.doi.org/10.1111/j.1574-6941.2012.01391.x

Cunnigham K.I., DuChene H.R. \& Spirakis C.S., 1993 Elemental sulfur in caves of the Guadalupe Mountains, New Mexico. New Mexico, Socorro: New Mexico Geological Society Guidebook $44^{\text {th }}$ Field conference, Carlsbad region, New Mexico and West Texas, p. 129-136.

Davis K.E., Joseph S.J \& Janssen P.H., 2005 - Effects of growth medium, inoculum size, and incubation time on culturability and isolation of soil bacteria. Applied and Environmental Microbiology, 71: 826-834.

http:/ /dx.doi.org/10.1128/AEM.71.2.826-834.2005

Edgar R.C., 2004 - MUSCLE: multiple sequence alignment with high accuracy and high throughput. Nucleic Acids Research, 32: 1792-1797.

http://dx.doi.org/10.1093/nar/gkh340

Fernandez-Cortes A., Cuezva S., Sanchez-Moral S., Cañaveras J.C., Porca E., Jurado V., MartinSanchez P.M. \& Saiz-Jimenez C., 2011 - Detection of human-induced environmental disturbances in a show cave. Environmental Science and Pollution Research, 18: 1037-1045.

http://dx.doi.org/10.1007/s11356-011-0513-5

Ferriss R.S. 1984 - Effects of microwave oven treatment of microorganisms in soil. Phytopathology, 74: 121126. http://dx.doi.org/10.1094/Phyto-74-121

Garcia M.G., Moya M., Spilde M.N., Stone F.D. \& Northup D.E. 2009 - Discovering new diversity in Hawaiian lava tube microbial mats. In: White W.B. (Ed.), Proceedings of the 15th International Congress of Speleology, 1: 364-369.

Hall T.A., 1999 - BioEdit: a user-friendly biological sequence alignment editor and analysis program for Windows 95/98/NT. Nucleic Acids Symposium Series, 41: 95-98.

Hardin G., 1960 - The Competitive Exclusion Principle. Science, 131: 1292-1297.

http://dx.doi.org/10.1126/science.131.3409.1292

Janssen P.H., Yates P.S., Grinton B.E., Taylor P.M. \& Sait M., 2002 - Improved culturability of soil bacteria and isolation in pure culture of novel members of the divisions Acidobacteria, Actinobacteria, Proteobacteria and Verrucomicrobia. Applied and Environmental Microbiology, 68: 2391-2396.

http://dx.doi.org/10.1128/AEM.68.5.2391-2396.2002

Johnston M.D., Millette J., Banks E.D., Jurado V. \& Barton H.A., 2011 - The culturable diversity of oligotrophic heterotrophs: the Lechuguilla cave culture library. New Orleans: Proceedings of the American Society for Microbiology General Meeting, N149, 1795 p. 
Johnston M.D., Muench B.A., Banks E.D. \& Barton H.A., 2012 - Human urine in Lechuguilla Cave: the microbiological impact and potential for bioremediation. Journal of Cave and Karst Studies, 74: 278-291. http://dx.doi.org/10.4311/2011MB0227

Jurado V., Boiron P., Kroppenstedt R.M., Laurent F., Couble A., Laiz L., Klenk H.P., González J.M., SaizJimenez C., Mouniée D., Bergeron E. \& Rodriguez-Nava V., 2008 - Nocardia altamirensis sp. nov., isolated from Altamira cave, Cantabria, Spain. International Journal of Systematics and Evolutionary Microbiology, 58: 2210-2214. http://dx.doi.org/10.1099/ijs.0.65482-0

Jurado V., Gonzalez J.M., Laiz L. \& Saiz-Jimenez C., 2006 - Aurantimonas altamirensis sp. nov., a member of the order Rhizobiales isolated from Altamira Cave. International Journal of Systematic and Evolutionary Microbiology, 56: 2583-2585.

http://dx.doi.org/10.1099/ijs.0.64397-0

Jurado V., Kroppenstedt R.M., Saiz-Jimenez C., Klenk H.P., Mouniée D., Laiz L., Couble A., Pötter G., Boiron P. \& Rodríguez-Nava V., 2009 - Hoyosella altamirensis gen. nov., sp. nov., a new member of the order Actinomycetales isolated from a cave biofilm. International Journal of Systematic and Evolutionary Microbiology, 59: 3105-3110.

http://dx.doi.org/10.1099/ijs.0.008664-0

Jurado V., Laiz L., Rodriguez-Nava V., Boiron P., Hermosin H., Sanchez-Moral S. \& Saiz-Jimenez C., 2010 - Pathogenic and opportunistic microorganisms in caves. International Journal of Speleology, 39: 15-24. http://dx.doi.org/10.5038/1827-806X.39.1.2

Keswick B.H., Wang D.S. \& Gerba C.P., 1982 - The use of microorganisms as ground-water tracers: a review. Groundwater, 20: 142-149. http://dx.doi.org/10.1111/j.1745-6584.1982.tb02741.x

Kim O.S., Cho Y.J., Lee K., Yoon S.H., Kim M., Na H., Park S.C., Jeon Y.S., Lee J.H., Yi H., Won S. \& Chun J., 2012 - Introducing EzTaxon-e: a prokaryotic 16S rRNA Gene sequence database with phylotypes that represent uncultured species. International Journal of Systematic and Evolutionary Microbiology, 62: 716721. http://dx.doi.org/10.1099/ijs.0.038075-0

Ko K.S., Oh W.S., Lee M.Y., Lee J.H., Lee H., Peck K.R., Lee N.Y. \& Song J.H., 2006 - Bacillus infantis $s p$. nov. and Bacillus idriensis $s p$. nov., isolated from a patient with neonatal sepsis. International Journal of Systematics and Evolutionary Microbiology, 56: 25412544. http://dx.doi.org/10.1099/ijs.0.64213-0

Laiz L., Gonzalez-Delvalle M., Hermosin B., OrtizMartinez A. \& Saiz-Jimenez, C., 2003 - Isolation of cave bacteria and substrate utilization at different temperatures. Geomicrobiology Journal, 20: 479-489. http://dx.doi.org/10.1080/713851125

Laffineur K., Avesani V., Cornu G., Charlier J., Janssens M., Wauters G. \& Delmée M., 2003 - Bacteremia due to a novel Microbacterium species in a patient with leukemia and description of Microbacterium paraoxydans $s p$. nov. Journal of Clinical Microbiology, 41: 2242-2246. http://dx.doi.org/10.1128/JCM.41.5.2242-2246.2003

Ma E.S., Wong C.L., Lai K.T., Chan E.C., Yam W.C. \& Chan A.C., 2005 - Kocuria kristinae infection associated with acute cholecystitis. BMC Infectious Diseases, 5: 60. http://dx.doi.org/10.1186/1471-2334-5-60

Moya, M., Garcia, M.G., Spilde, M.N. \& Northup, D.E., 2009 - Composition of bacterial mats in El Malpais, National Monument, New Mexico, USA: comparison and contrasts with bacterial communities in Hawai'i lava tubes. In: White W.B. (Ed.), Proceedings of the $15^{\text {th }}$ International Congress of Speleology, 2: 709-713.
Mulec J., 2008 - Microorganisms in hypogeon: examples from Slovenian karst caves. Acta Carsologica, 37: 153-160.

Niyomvong N., Pathom-Aree W., Thamchaipenet A. \& Duangmal K., 2012 - Actinomycetes from tropical limestone caves. Chiang Mai Journal of Science, 39: 373-388.

Northup D.E., Carr D.L., Crocker M.T., Cunningham K.I., Hawkins L.K., Leonard P. \& Welbourn W.C., 1994 - Biological investigations in Lechuguilla Cave, Carlsbad Caverns National Park, New Mexico. Bulletin of the National Speleological Society, 56: 54-63.

Northup, D.E., Connolly, C.A., Trent, A., Peck, V.M., Spilde, M.N., Welbourn, W.C. \&

Natvig, D.O. 2008 - The nature of bacterial communities in Four Windows Cave, El Malpais National Monument, New Mexico, USA. AMCS Bulletin 19: 119-125.

Northup D.E., Melim L.A., Spilde M.N., Hathaway J.J.M., Garcia M.G., Moya M., Stone F.D., Boston P.J., Dapkevicius M.L.N.E. \& Riquelme C., 2011 - Lava cave microbial communities within mats and secondary mineral deposits: implications for life detection on other planets. Astrobiology, 11: 601-618. http://dx.doi.org/10.1089/ast.2010.0562

Palmer A.N., Palmer M.V. \& Davis D.G., 1991 - Geology and origin of Lechuguilla cave. In: Taylor M.R. (Ed.), Lechuguilla-Jewel of the underground, Speleoprojects, Basel, Switzerland: 22-31.

Pašić L., Kovče B., Sket B. \& Herzog-Velikonja B., 2010 - Diversity of microbial communities colonizing the walls of a Karstic cave in Slovenia. FEMS Microbiology Ecology, 71: 50-60. http://dx.doi.org/10.1111/j.1574-6941.2009.00789.x

Porca E., Jurado V., Žgur-Bertok D., Saiz-Jimenez C. \& Pašić L., 2012 - Comparative analysis of yellow microbial communities growing on the walls of geographically distinct caves indicates a common core of microorganisms involved in their formation. FEMS Microbiology Ecology, 81: 255-266.

http://dx.doi.org/10.1111/j.1574-6941.2012.01383.x

Portillo M.C., Gonzalez J.M. \& Saiz-Jimenez C., 2008 - Metabolically active microbial communities of yellow and grey colonizations on the walls of Altamira Cave, Spain. Journal of Applied Microbiology, 104: 681-691. http://dx.doi.org/10.1111/j.1365-2672.2007.03594.x

Portillo M.C., Saiz-Jimenez C. \& Gonzalez J.M., 2009 Molecular characterization of total and metabolically active bacterial communities of 'white colonization' in the Altamira Cave, Spain. Research in Microbiology, 160: 41-47.

http://dx.doi.org/10.1016/j.resmic.2008.10.002

Rusterholtz K.J. \& Mallory L.M., 1994 - Density, activity, and diversity of bacteria indigenous to a karstic aquifier. Microbial Ecology, 28: 79-99.

http://dx.doi.org/10.1007/BF00170249

Schabereiter-Gurtner C., Saiz-Jimenez C., Piñar G., Lubitz W. \& Rölleke S., 2004 - Phylogenetic diversity of bacteria associated with palaeolithic paintings and surrounding rock walls in two Spanish caves (Llonin and La Garma). FEMS Microbiology Ecology, 47: 235-247. http://dx.doi.org/10.1016/S0168-6496(03)00280-0

Schloss P.D., Westcott S.L., Ryabin T., Hall J.R., Hartmann M., Hollister E.B., Lesniewski R.A., Oakley B.B., Parks D.H., Robinson C.J., Sahl J.W., Stres B., Thallinger G.G., Van Horn D.J., Weber C.F., 2009 Introducing mothur: open-source, platform-independent, community-supported software for describing and comparing microbial communities. Applied and Environmental Microbiology, 75: 7537-7541. http://dx.doi.org/10.1128/AEM.01541-09 
Seong C.N., Choi J.H. \& Baik K-S., 2001 - An improved selective isolateion of rare actinomycetes from forest soil. The Journal of Microbiology, 39: 17-23.

Tamura K., Peterson D., Peterson N., Stecher G., Nei M. \& Kumar S., 2011 - MEGA5: molecular evolutionary genetics analysis using maximum likelihood, evolutionary distance, and maximum parsimony methods. Molecular Biology and Evolution, 28: 27312739. http://dx.doi.org/10.1093/molbev/msr121

Vela A.I., Gutiérrez M.C., Falsen E., Rollán E., Simarro I., García P., Domínguez L., Ventosa A. \& FernándezGarayzáabal J.F., 2006 - Pseudomonas simiae sp. nov., isolated from clinical specimens from monkeys (Callithrix geoffroyi). International Journal of Systematics and Evolutionary Microbiology, 56: 2671-2676. http://dx.doi.org/10.1099/ijs.0.64378-0
Wang D.S., Xue Q.H., Zhu W.J., Zhao J., Duan J.L. \& Shen G.H., 2013 - Microwave irradiation is a useful tool for improving isolation of actinomycetes from soil. Microbiology 82: 102-110.

http://dx.doi.org/10.1134/S0026261712060161

Wellington E.M.H. \& Cross T., 1983 - Taxonomy of antibiotic producing Actinomycetes and new approaches to their selective isolation. In: Bushell M.E. (Eds.), Progress in industrial microbiology? Elsevier, Amsterdam. pp. 36.

Yokota A., Takeuchi M., Sakane T. \& Weiss N., 1993 Proposal of six new species of the genus Aureobacterium and transfer of Flavobacterium esteraromaticum Omelianski to the genus Aureobacterium as Aureobacterium esteraromaticum comb. nov. International Journal of Systematics and Bacteriology, 43: 555-564. http://dx.doi.org/10.1099/00207713-43-3-555 